\title{
Study on Status and Investment Opportunity of Construction Industry Chain in Malaysia
}

\author{
Hao Yin \\ International Business School \\ Yunnan University of Finance and Economics \\ Kunming, China \\ yinhaoli@163.com \\ Ying Gao* \\ International Business School
}

\author{
Yunnan University of Finance and Economics \\ Kunming, China \\ gaoying921225@126.com
}

Zhaojing An

International Business School

Yunnan University of Finance and Economics

Kunming, China

anzhaojing@163.com

\begin{abstract}
Malaysia is an important country which located in the strategic pass of Maritime Silk Road in twenty-first Century, which joined the Asian Infrastructure Investment Bank in 2015 as the founding members. In the next few years, Malaysia investment enterprises will transform small projects into major projects, which have important significance to the development of Malaysia construction market. Firstly, development status of construction industry chain in Malaysia were analyzed from aspects of fund sources, construction material, construction machinery, fuel and power supply. Secondly, investing opportunity in construction market was studied from the views of industry chain, segment market, key region market. Finally, proposal of developing the construction industry chain for foreign investor was discussed. It is found that there is large space of investment in the construction industry chain in Malaysia.
\end{abstract}

Keywords—investment opportunity; construction industry chain; malaysia

\section{INTRODUCTION}

The construction industry is an important sector of Malaysia's national economy. The construction industry was in the growth of the $-1.6 \%$ and $-0.5 \%$ level in 2005 and 2006, The next five years, the construction industry was improved, but the pace was still faltering growth. In recent years, the growth rate of construction industry was $10 \%$, and the overall development was relatively steady. Malaysia will strengthen public transportation and infrastructure construction from 2016 to 2020, and invest many large-scale infrastructure construction projects, such as the high-speed rail project between Malaysia and Singapore, Malaysia City, etc. This will be a key pillar to support and be of great significance the development of the construction industry over the next ten years or more. In addition, rich resources and diversified environment also attracted more and more multinational construction enterprises in Malaysia. The aim in the paper is to analyze the status and investment opportunity of construction industry chain in Malaysia.

\section{THE DEVELOPMENT STATUS OF CONSTRUCTION INDUSTRY CHAIN IN MALAYSIA}

\section{A. The General Situation of Malaysia Construction Market}

Malaysia carry out the investment system combined with the market and the national project. The system applied in the construction market and real estate development. General civil engineering projects are the market readjustment, pricing, market turnover, such as private real estate development projects, self-financing projects, financing projects, etc. The project of national government carries out a combination of public bidding, direct arrangements and private consultations. Construction project carry out budget settlement system. The price of construction of the project set by the State and adjust periodically, such as steel, cement, wood, sand, stone and other 12 kinds of building materials. Other building materials are traded at market prices. Engineering settlement, such as national material pricing super price, the contracting party give compensation. Payment of the project is relatively standardized, give $15 \%$ of the advance payment and then payment by installments in the progress schedule. Therefore, the income of construction enterprise is guaranteed, and profit is considerable. Generally, the average net profit of Malaysia construction project is between $10 \%$ to $15 \%$ [4].

\section{B. The Funding Sources of Malaysia Construction Project}

\section{1) Fiscal revenue and expenditure}

About 25\%of Malaysian government revenue comes from crude oil, including oil income taxes, oil dividends and oil taxes. The price of oil was about $\$ 48$ a barrel as a benchmark in the budget. However, because of international crude oil prices continued to fall, Malaysia's current oil price is only $\$ 36$ a barrel. There is a difference of $\$ 12$ between the two.

\footnotetext{
* Corresponding author
} 
Malaysia petroleum tax may be reduced by 4 billion to 5 billion ringgits. (Note: $1 \mathrm{USD}=3.9888 \mathrm{MYR}$, August 18, 2016)

To deal with the oil price rate down, in January 2016, Malaysian government took the initiative to adjust the budget. The measures were cutting administrative expenses, increasing the purchasing power of domestic products, and promoting tourism development, etc. The aim was to ensure balanced and stable and mature economic growth, and to stimulate exports and service sector, Meanwhile, Malaysian government continued to carry out financial reform and rectification plan.

\section{2) Major financial institutions in Malaysia}

\section{a) Banking institutions}

The Central Bank of Malaysia is the National Bank. It is responsible for maintaining the stability of the national currency, regulating and supervising banks, financial and insurance institutions, and issuing national currency ringgit.

Malaysian local commercial banks are: Malaysia bank, CIMB bank, native public bank, Hong Leong bank and Societe Generale Bank etc.

The foreign banks in Malaysia include: Citibank, HSBC, Standard Chartered Bank, Bank of America, Deutsche Bank, overseas Chinese bank, Bank of China and ICBC.

\section{b) Securities market}

The Kuala Lumpur stock exchange is the only stock market in Malaysia. It deals with stocks, futures, bonds, derivatives and so on. It is divided into two parts: The Main Market and the ACE Market.

\section{3) Financial support from World Bank}

The world bank loan to Malaysia paid off all the project a total of 122 items, including currency pool loans, fixed rate single currency loans, non-performing loans, single currency pool loans.

\section{The Situation of Construction Material and Machinery in Malaysia}

\section{1) Construction materials supply}

\section{a) Crude steel}

Malaysia is the largest steel producer in Southeast Asia. In 2014, crude steel production reached 5 million tons, an increase of $6.54 \%$ compared to 2013.After the free trade in Malaysia, the steel industry began to face pressure from imported steel. Malaysian upstream enterprise of smelting iron and steel capacity hope to take protective measures. However, downstream enterprises want to free import steel, which also indicates that the local hot rolling capacity is obviously insufficient.

The main local steelmakers are: Malaysia Hiap Teck Venture Berhad, founded in 1987, is a major steel factory in
Malaysia, which produce various steel products, including: Black welded steel pipe, steel tubes for furniture, waterpipe, beam channel, hot galvanized channel steel etc.

\section{b) Cement}

Lafarge Malaysia、YTL Cement 、 Tasek Corp and CIMA (Cement Industries of Malaysia Berhand) are Malaysia's main cement producer, accounting for $96 \%$ of Malaysia's total cement output.

Lafarge Malaysia cement production capacity is 12 million 950 thousand tons, YTL Cement to 5 million 950 thousand tons followed, CIMA is 3 million 400 thousand tons, Tasek Corp production capacity is 2 million 300 thousand tons, Hume Cement and Holcim Malaysia production capacity is 2 million tons respectively.

The average price of reinforced concrete in various regions in Malaysia construction market are different. However, the basic per metric ton is around RM 2200-2500. (See TABLE. I )

TABle I. Average Prices Of Steel And Cement (November 2013) UNIT: MYR

\begin{tabular}{|c|c|c|c|}
\hline \multirow{2}{*}{ Building material } & \multicolumn{3}{|c|}{ Region } \\
\cline { 2 - 4 } & North & Midlands & East \\
\hline Round Steel Bar BS-4450 & \multicolumn{3}{|c|}{ Ringgit/per metric ton } \\
\hline $10 \mathrm{~mm}$ & 2424 & 2387 & 2591 \\
\hline $12 \mathrm{~mm}$ & 2427 & 2381 & 2584 \\
\hline $16 \mathrm{~mm}$ & 2322 & 2342 & 2491 \\
\hline $20-25 \mathrm{~mm}$ & 2348 & 2358 & 2552 \\
\hline $32 \mathrm{~mm}$ & 2294 & 2413 & 2501 \\
\hline $\begin{array}{c}\mid 3 \\
\text { High strength pre-stressed } \\
\text { steel bar }\end{array}$ & 2424 & 2429 & 2608 \\
\hline $10 \mathrm{~mm}$ & 2427 & 2425 & 2608 \\
\hline $12 \mathrm{~mm}$ & 2318 & 2313 & 2561 \\
\hline $16-25 \mathrm{~mm}$ & 2302 & 2295 & 2484 \\
\hline $32 \mathrm{~mm}$ & \multicolumn{3}{|c|}{ Ringgit/50 kg metric ton } \\
\hline Cement & 17.8 & 17.7 & 16.9 \\
\hline BS12 &
\end{tabular}

Data source: Malaysia Bureau of national construction industry development Note: 1 USD=3.2094 MYR (December 2013)

\section{2) Construction machinery supply}

Malaysia construction machinery output can only meet less than $20 \%$ of the demand. [1] So, Malaysia still has great demand for imported construction machinery. At present, the only assembled equipment locally is the packer.

Other machinery mostly need to import, such as excavators, bulldozers, concrete mixers, and other equipment. Part of the machinery rental price. (See TABLE. II) 
TABLE II. PART Of MACHINERy LeAsing Price List (JANUARY AND JULY 2013, SELANGOR)

\begin{tabular}{|c|c|c|c|c|c|c|}
\hline \multirow{2}{*}{ Number } & \multirow{2}{*}{$\begin{array}{c}\text { Mechanical } \\
\text { Name }\end{array}$} & Specifications & \multicolumn{2}{|c|}{ January (MYR) } & \multicolumn{2}{|c|}{ July (MYR) } \\
\cline { 4 - 8 } & & $\begin{array}{c}\text { Daily } \\
\text { Rent }\end{array}$ & $\begin{array}{c}\text { Monthly } \\
\text { Rent }\end{array}$ & $\begin{array}{c}\text { Daily } \\
\text { Rent }\end{array}$ & $\begin{array}{c}\text { Monthly } \\
\text { Rent }\end{array}$ \\
\hline 1 & excavator & $56 \mathrm{KW}$ & 417 & 6633 & 450 & 6650 \\
\hline 2 & Compactor & & 537 & 7700 & 537 & 7700 \\
\hline 3 & $\begin{array}{c}\text { Hydraulic } \\
\text { crawler crane }\end{array}$ & $\begin{array}{c}\text { hoisting } \\
\text { capacity60 tons }\end{array}$ & 1333 & 16233 & 1333 & 16233 \\
\hline 4 & Mobile crane & $\begin{array}{c}\text { Hoisting } \\
\text { capacity20 tons }\end{array}$ & 500 & 7967 & 500 & 7967 \\
\hline 5 & Bulldozer & 60 cubic metres & 1150 & 13600 & 1150 & 13600 \\
\hline 6 & $\begin{array}{c}\text { Self-dischargi } \\
\text { ng truck }\end{array}$ & 10 tons & 677 & 11933 & 677 & 11933 \\
\hline
\end{tabular}

Data source: Malaysia Bureau of national construction industry development

\section{3) Transport vehicle supply}

Malaysia native car manufacturing industry has a certain basis, but mainly to passenger cars. In 2015, the total output of automobiles reached 614664, of which 563883 were passenger cars, accounting for $91.74 \%$. In 2014, the output of heavy truck was only 5100 , up by $10.4 \%$ in 2013 [5].

\section{Fuel and power supply}

\section{1) fuel supply}

Malaysia fossil fuels are: lignite, oil shale, natural gas, oil. Among them, the oil shale reserves about 1 million 870 thousand tons, lignite reserves about 20 tons, natural gas reserves of about 16 trillion and 400 billion cubic feet,15 million tons of oil reserves.

Malaysia oil carries out floating price system. By April 15,2014 , the retail price of unleaded petrol 97 was 2.9 MYR per liter, and the retail price of unleaded gasoline 95 was 2.1 MYR per liter, and the retail price of gasoline was 2 MYR per liter.

\section{2) Power supply}

Malaysia power is provided by public energy companies, accounting for $98 \%$, and independent private power plants, accounting for $2 \%$. Among them, public energy companies, including the national energy company and the state energy company. The main structure of power supply is gas generating units, followed by coal-fired units and Hydropower units.

In 2013, the generating capacity was about 131 billion 850 million kwh. (See TABLE. III)

Annual installed capacity is 26 million 55 thousand kilowatts. Electricity demand peak is 19 million 589 thousand kilowatts, and spare margin accounted for $33 \%$.

Since 2001, Malaysian government has ranked renewable energy as the fifth source of energy for the country. But the development of renewable energy has been extremely slow. The Malaysia power plant is facing a natural gas supply It had an impact on the cost of regular power generation and electricity generation. So, there is a slight difference in the price of electricity between the East and west in Malaysia [3].

Table III. Percentage Of Each Unit Generating Capacity In 2013

\begin{tabular}{|c|c|}
\hline gas generating units & $45.3 \%$ \\
\hline coal-fired units & $38.5 \%$ \\
\hline hydropower generating units & $10.6 \%$ \\
\hline gasoline units & $5.4 \%$ \\
\hline other & $0.2 \%$ \\
\hline
\end{tabular}

\section{ANALYSIS Of InVESTMENT OpPORTUNITY In MALAYSIA \\ CONSTRUCTION MARKET}

\section{A. Investment opportunities of industry chain}

1) Construction market investment opportunities

Malaysia is a major construction demand country in the ASEAN region. In addition to its own production of some construction products, Malaysia need to rely on imports. Although the Malaysia local building to produce mineral resources are abundant, and Malaysia overall market capacity is limited, and factors of production price is higher. Therefore, compared with setting up factory, the development of export trade will be the most suitable way. It can make foreign building materials manufacturers to enter the Malaysia market.

2) Investment opportunity analysis of construction machinery market

The highway, railway and other traffic construction are to achieve the Malaysia States and Malaysia and the external interconnection. Many transportation, infrastructure, energy projects will bring considerable market demand for construction machinery. The neighboring countries of construction machinery has a natural advantage, whether the exports, or engineering contractor involved in local infrastructure. It will drive the world construction machinery exports.

\section{B. Investment opportunities of segment market}

The project includes Malaysia residential and non-residential, social welfare facilities, infrastructure construction. The number of residential projects accounted for about $29 \%$, residential projects accounted for the total value of about $30 \%$; the number of nonresidential projects accounted for about $36 \%$, the value of the overall upward trend. However, the number of social welfare facilities and infrastructure is a downward trend. (See TABLE. IV)

\section{1) Transportation infrastructure construction project}

Transportation infrastructure is a key area. Key projects include: the highway network in Gemas city to the town of Johor Bazhou sand double track railway, Bazhou and Sarawak sand etc. 
TABLE IV. Statistics Of Number And Sum Of Projects In Malaysia

(UNIT: MILLION RINGGIT)

\begin{tabular}{|c|c|c|c|c|}
\hline \multirow{2}{*}{ Total } & & 2012 & 2013 & 2014 \\
\hline \multirow{2}{*}{ Residential } & Number of projects & 7892 & 8028 & 5790 \\
\cline { 2 - 5 } & Sum of projects & 127616 & 130719 & 108600 \\
\cline { 2 - 5 } & Number of projects & 2276 & 2302 & 1716 \\
\hline \multirow{2}{*}{\begin{tabular}{c} 
Non-residential \\
\cline { 2 - 5 }
\end{tabular}} & Sum of projects & 33213 & 37901 & 33182 \\
\cline { 2 - 5 } $\begin{array}{c}\text { Social welfare } \\
\text { facilities }\end{array}$ & Sum of projects & 41058 & 51897 & 48341 \\
\cline { 2 - 5 } & Number of projects & 906 & 723 & 523 \\
\hline \multirow{2}{*}{$\begin{array}{c}\text { Infrastructure } \\
\text { construction }\end{array}$} & Sum of projects & 7311 & 9613 & 6201 \\
\cline { 2 - 5 } & Number of projects & 1863 & 2008 & 1466 \\
\hline \multicolumn{2}{|c|}{ Sum of projects } & 46034 & 31308 & 20875 \\
\hline
\end{tabular}

Data source: Malaysia Bureau of national construction industry development

\section{2) Real estate project}

Firstly, the residential market opportunity

\section{a) The local ordinary housing project}

At present, the relevant departments of the Malaysian government are discussing how to implement 1 million affordable housing projects within 5 years, including housing distribution, such as urban, urban sideline or rural areas. (See TABLE. V)

TABLE V. Statistics Of The Number And Sum Of Residential ProjeCts (MiLlion RINGGIT)

\begin{tabular}{|c|c|c|}
\hline Year & Number of projects & Sum of projects \\
\hline 2012 & 2276 & $33,213.09$ \\
\hline 2013 & 2302 & $37,901.09$ \\
\hline 2014 & 1716 & $33,181.90$ \\
\hline
\end{tabular}

Data source: Malaysia Bureau of national construction industry development

\section{b) From foreign demand for housing}

Most of the local population has no demand for buying a house in Malaysia, only a few large cities such as Kuala Lumpur residents have real estate investment awareness. Therefore, Malaysia residential market demand mainly rely on foreign power.

The Malaysian government Immigration Department launched a plan. The plan allowed foreigners to buy two sets of the above property value of 500 thousand ringgit without approval, and cancel the industry profits tax, obtain unlimited industry loans. If the sale must pay $5 \%$ of the industry profits tax within 5 years, after 5 years, you can exempt from the industry profits tax. The Malaysia government planned to attract foreign capital, promote tourism and develop the economy. The aim is to encourage foreigners to live in Malaysia for a long time. [8]

Secondly, commercial real estate market opportunity (See TABLE. VI)
TABLE VI. Statistics Of The Number And Sum Of Non-Residential

Projects (Unit: MiLlion RingGit)

\begin{tabular}{|c|c|c|}
\hline Year & Number of projects & Sum of projects \\
\hline 2012 & 2847 & $41,057.99$ \\
\hline 2013 & 2995 & $51,896.62$ \\
\hline 2014 & 2085 & $48,341.22$ \\
\hline \multicolumn{2}{|c|}{ Data source: Malaysia Bureau of national construction industry development } \\
\hline
\end{tabular}

\section{c) Office building}

According to CIMB estimates, in 2015 to 2017 , the total area of the office buildings completed and put into operation is approximately 17 million square feet. The total supply of office buildings far exceeds the demand. It should be noted that the Malaysia vacancy rate of first-class office buildings is relatively low. So, the office market although have excess risk, but there are opportunities for structured market segments.

\section{d) Hotel market}

According to the tourism development target in 2020, it will attract 36 million international passengers. The calculation of accommodation demand: demand for accommodation beds=annual number of visitors* accommodation ratio*average accommodation days / (number of days to visit*beds utilization rate).

In 2012, the number of domestic tourists was 141 million 433 thousand, of which the hotel accommodation was only $14.1 \%$. According to the above formula, the corresponding bed demand was 273179. The number of the Malaysia hotel in 2012 was 2724, and the number of beds was close to 400 thousand. (See TABLE. VII)

Even if Malaysia does not consider the growth of domestic tourists. In 2012, there are 36 million people of foreign tourists' bed demand. The Malaysia hotel has a gap of more than 100 thousand.

From the hotel distribution, most of the hotels are concentrated in Kuala Lumpur, Selangor and other tourist city, accounted for about $60 \%$ among the Malaysia hotel, the hotel market is regional investment opportunities. In addition to unbalanced regional development, the proportion of Malaysia five-star hotel is relatively low.

TABLE VII. DEMAND ForeCAST OF ACCOMMODATION Beds For FOREIGN TOURISTS

\begin{tabular}{|c|c|}
\hline Index & 2020 \\
\hline Total number of visitors, thousand passengers & 36000 \\
\hline Accommodation ratio & $50 \%$ \\
\hline Average stay days & 3 \\
\hline Number of days to visit & 365 \\
\hline Bed utilization rate & $60 \%$ \\
\hline Demand for accommodation beds & 246575 \\
\hline
\end{tabular}

Data source: Malaysia Bureau of national construction industry development

e) Shopping Center

Because of the duty-free system, Malaysia is the most 
important shopping center in Southeast Asia. Many people from Hongkong and Singapore like to go shopping there at weekends. The main city of Kuala Lumpur, Penang, Johor and Badong Besar are equipped with duty-free shops.

Although Malaysia has a population of less than thirty million. As a regional and international shopping center, supporting Malaysia shopping center development was from external demand. The market has not yet saturated, and there is still large space for the development of new projects.

Thirdly, Malaysia schools, hospitals and other urban public facilities construction project investment opportunities. (See TABLE. VIII)

TABLE VIII. Number AND Sum Of Social Welfare Facilities

\begin{tabular}{|c|c|c|}
\hline Year & Number of projects & Sum of project \\
\hline 2012 & 906 & $7,310.59$ \\
\hline 2013 & 723 & $9,612.56$ \\
\hline 2014 & 523 & $6,200.78$ \\
\hline
\end{tabular}

Data source: Malaysia Bureau of national construction industry development

Note: 1 USD=3.2094 MYR (December 2013)

Compared with the major Southeast Asian countries and China. The medical infrastructure is relatively backward. From the population structure, the population of Malaysia has shown the trend of aging. In the past 2000-2010 years, the proportion of people over the age of 65 has increased by $1.2 \%$, reached $5.1 \%$. At this rate, Malaysia's population over the age of 65 will exceed $6 \%$ in 2018 . With the growth of population, aging population and the number of immigrants, the demand for related education and medical infrastructure has also increased. (See TABLE. IX)

TABLE IX. Comparison Of Hospital Bed Index Between Malaysia And Some Southeast Asian Countries And China

\begin{tabular}{|c|c|}
\hline Country & Hospital beds per million people \\
\hline Vietnam & 31 \\
\hline Thailand & 21 \\
\hline Singapore & 31 \\
\hline Indonesia & 6 \\
\hline China & 42 \\
\hline Malaysia & 18 \\
\hline
\end{tabular}

Data sources:2013 China Health Statistics Yearbook

C. Investment opportunities in key regions

In 2006, to achieve the balanced development of society and economy, the developed countries have been among the 2020 Vision. Malaysian government will set up 5 regional economic development corridor. According to the regional industry and the natural conditions, the government make different development strategy and industrial cluster policy. Besides, there are taxation, land, employment of foreign workers and a variety of reasons to attracts domestic and foreign investment in key industries of various regions.

\section{1) Iskandar Economic Corridor}

As the first to set up the corridor, the Iskandar will be established for the international industrial and service center. The key industries including electronics, petroleum and oil chemistry, food processing, and other manufacturing industries based on agriculture. Under the ninth and the ten Malaysia Plan, the government endorsed a total of 7 billion 300 million ringgit in Iskandar. Until November 2012, the Iskandar attracted a total of 105 billion 100 million ringgit's investment, including $64 \%$ domestic investment, 36\% for foreign investment. It will estimate to create a total of 154000 jobs.

\section{2) Special Economic Zone in the Northern Corridor}

The Northern Corridor Economic Zone is in Malaysia agricultural area, and has 40 years' experience in the semiconductor industry. So, it is planning for the center of agriculture and high-tech development. Tourism, logistics and education are listed as its key development projects. Since 2008, a total of 29 billion 700 million ringgit attracted, creating 42602 jobs. The Biotechnology Center in Wuda set up Malaysia's first native LED certification and testing center. Besides, the Executive Board of the northern economic corridor, and the public, private, academic education, the three departments set up joint research the development of electronic industry in Engineering Technology. Meanwhile, the departments make a 3-year talent blueprint for the electronics industry.

\section{3) East Coast Corridor Special Economic Zone}

The main development projects are tourism, petrochemical, oil and gas, agriculture, education and manufacturing. In order to attract private investment. Over the past 3 years, the federal government has invested 3 billion in port, road and other infrastructure, prompted the east coast to attract 12 billion commitment investment in 2012, higher the current target of $20 \% ; 75 \%$ of which are from domestic investment.

\section{4) Sabah Development Corridor}

Sabah is the world's third largest palm oil production. Although the Sabah development corridor infrastructure is relatively backward, the authorities can use the rich resources. There are natural assets, biotechnology, and geothermal and biomass energy and other alternative energy related industries to attract investment about 114 billion ringgits since 2008 . At the end of 2012, the federal government approved a series of investment incentives measures. Tax incentives are to develop Kinabalu Gold Coast Beach, sand bass Banon Industrial Park and Sabah oil and gas industry park, integrated livestock Center, marine comprehensive area and palm oil industry comprehensive area in Lahad Datu [2]. 


\section{IV.Proposal OF INVESTMENT IN MALAYSIA CONSTRUCTION}

\section{MARKET INDUSTRY CHAIN}

\section{A. Malaysia construction market industry chain diversified investment}

Malaysia is rich in natural resources. Rubber, palm oil and pepper yield and export volume ranks first in the world. It used to be the biggest producer of tin in the world, and its output has been decreasing year by year. Malaysia is rich in oil reserves, in addition to iron, gold, tungsten, coal, bauxite, manganese and other minerals and tropical hardwoods.

Though the construction industry chain project, Investors can choose to be selective participation in resource development from the related field of mineral resources. Combined the construction market and resource development to cultivate and bring new profit source.

\section{B. Malaysia construction market management localization industry chain proposal}

\section{1) Enterprise localization}

In the construction market, some areas are not open to foreign enterprises. For example, the government projects cannot allow foreign investment to enter, allowing only domestic construction enterprises to undertake construction. If a foreign construction enterprise wants to contract to build a government project, it must form a consortium with local enterprises. Under this policy, the company has actively sought local partners to establish a strategic partnership and participate in government project; on the other hand, the foreign enterprises actively seek to acquire local construction enterprise with development advantages. The foreign enterprise can realize the localization and break the trade barriers. It is good for enhance the company's marketing quality and the development of quality [6].

\section{2) Localization of labor services}

Malaysia has been allowed to employ foreign workers the construction industry, because of a shortage of domestic labor. Since the outbreak of the global fiscal crisis in 2008, the Malaysian government temporarily blocked the introduction of foreign workers in some areas. Foreigners who work in Malaysia must obtain work permits.

Under the foreign labor policy becoming stricter and stricter, investors can consciously enhance their skills training in addition to the advantages of low local labor costs. On the one hand, it is beneficial to the operation of the construction project, on the other hand. It can also improve Malaysia local employment rate and maintain good relations. It is beneficial to the construction market related business lasting health management.

\section{Malaysia construction market chain project financing}

For investors, it is a significant importance to the project feasibility study and preliminary investigation. The significance is not only as a working document of financing.
Also, partners can have a detailed understanding of the internal and external environment of the project. And it is very important to change the traditional mode of operation of the overseas investment of domestic enterprises.

Enterprises intend to invest overseas and should establish a database of overseas investment through preliminary market research work. A detailed and systematic study is made of the laws, policies, taxes, services and other circumstances of the investment target market, as well as the local market conditions and the investment environment of the products to be invested [7].

Based on the detailed research, enterprises should pay close attention to the overseas project information. When there are investment opportunities, enterprises can rapidly complete the project evaluation of the external environment so that make the project investigation into early stage. It can improve the efficiency and success rate of the operation of the project. It is essential to seek support from professional organizations, such as professional consulting firms, law firms, accounting firms, etc.

\section{CONCLUSION}

Malaysia is political stability, social stability, and economic development. The legal environment is relatively perfect, and have rich in resources, cultural diversity, excellent investment environment. The rapid growth has spawned a large demand for construction products, attracting multinational companies from many construction industries to invest in Malaysia.

Firstly, Malaysia has a rich material resources. Steel, cement and other bulk building materials basically meet the needs of some construction projects. Part of the project in the construction of local procurement of materials reached $100 \%$, Then Malaysia is short of labor and allows foreign laborers to be employed in the construction field. It is an opportunity for foreign workers to work in the construction industry, Finally, in addition to improve public transport projects, the government will launch many infrastructure projects. It is a powerful impetus for the construction industry. Therefore, whether it is the resource situation, investment policy, or a series of preferential policies and various aspects of the construction market conditions. The development potential of the construction market in Malaysia is enormous.

\section{ACKNOWLEDGMENT}

We would like to express our sincere gratitude to the director Mr. Tan xiaojun of the Yunnan Business Representative Office in Malaysia, for supporting us in research with collection data. We also want to thank the anonymous reviewers for their comments.

\section{REFERENCE}

[1] H.B. Zhao, L. Zheng, "Malaysia Tax Policy and GST Introduction," 
Business, 2015, p. 187.

[2] H. Chen, "First Study of Tax Policy and Investment Incentives in Malaysia," International Business Daily, 2013.

[3] H. Yu, "Renewable Energy Ushered in A New Opportunity," China Energy News, 2011.

[4] J. Zhou, "Contracting Projects should be Localized," International Business Daily, 2010.
[5] S.P. Shang, "Environment and Characteristics of Construction Market in Western Asia," International Engineering and Services, 2014, pp.30-32.

[6] S.P. Shang, "Outlook of Contract Engineering Market," International Engineering and Services, 2015, pp.49-52.

[7] S.P. Shang, and R.B Weng, "Malaysia Contract Engineering Market," International Engineering and Services, 2013(07) pp. 24-26.

[8] Z.H. Wei, "Malaysia: Review and Prospect of the 2011 2012 Year," Southeast Asia, 2012, pp. 22-30 